\title{
Integration of geophysical, hydrogeological and geospatial analysis for groundwater assessment in Chotanagpur Granite-Gneiss Complex, Ranchi
}

\author{
Gaurav Kumar ${ }^{1}$, Dewashish Kumar ${ }^{2}$, and Pratibha Warwade ${ }^{1}$ \\ ${ }^{1}$ Central University of Jharkhand \\ ${ }^{2}$ National Geophysical Research Institute, Hyderabad, India
}

June 22, 2021

\begin{abstract}
Integrated study combining electrical resistivity tomography, geology, hydrogeomorphology, and weighted overlay analysis of various surface and subsurface thematic layers proved to be a very useful tool for evaluating the heterogeneous hard aquifer systems for groundwater assessment and development. A comprehensive study was carried out at representative and varied geological settings viz., Chotanagpur Granite-Gneiss Complex (CGGC), Ranchi has been accomplished from geology and geophysical datasets. The electrical resistivity tomography results revealed potential target zones at three sites in the study area up to a maximum of $170 \mathrm{~m}$ depth with a large variation in aquifer resistivity ranging from 80 to $800 \Omega$.m. These significant findings depicted a good correlation and are validated with the lithology in the surrounding of the resistivity tomography results. Nevertheless, the weighted overlay technique act as an essential tool for spatial analysis and interpretation of potential groundwater zones in the study area as well as validated the geophysical depth models whereas in-depth study on geology and hydrogeomorphology provides a detailed hydrogeological scenario throughout the study area for the long-term sustainability of the groundwater resources both at a local and in regional scale in the typical hard rock aquifer system.
\end{abstract}

\section{Hosted file}

Full Manuscript_CGGC-Ranchi_Updated 2nd June, 2021.docx available at https://authorea.com/ users/421057/articles/527223-integration-of-geophysical-hydrogeological-and-geospatialanalysis-for-groundwater-assessment-in-chotanagpur-granite-gneiss-complex-ranchi 

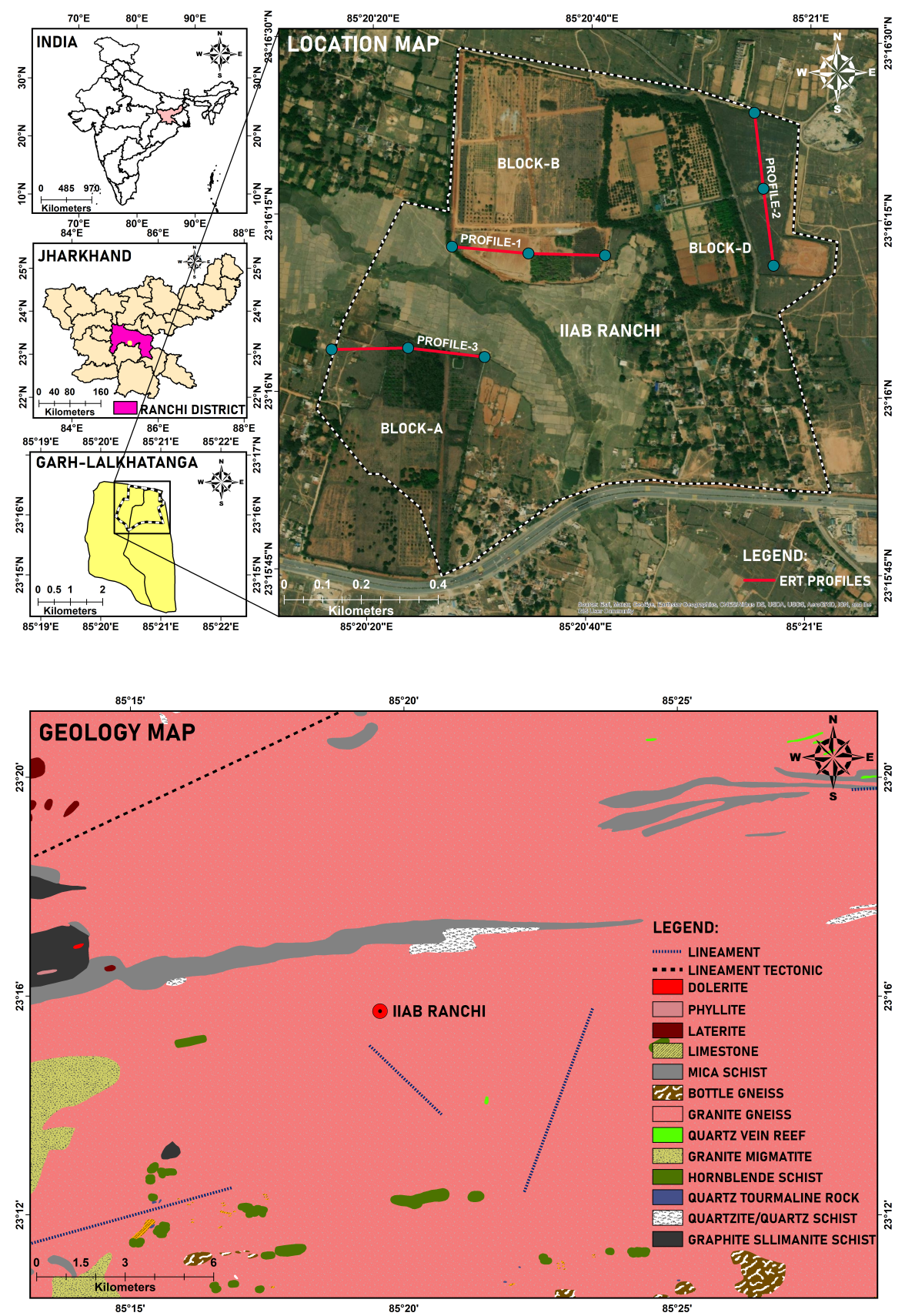

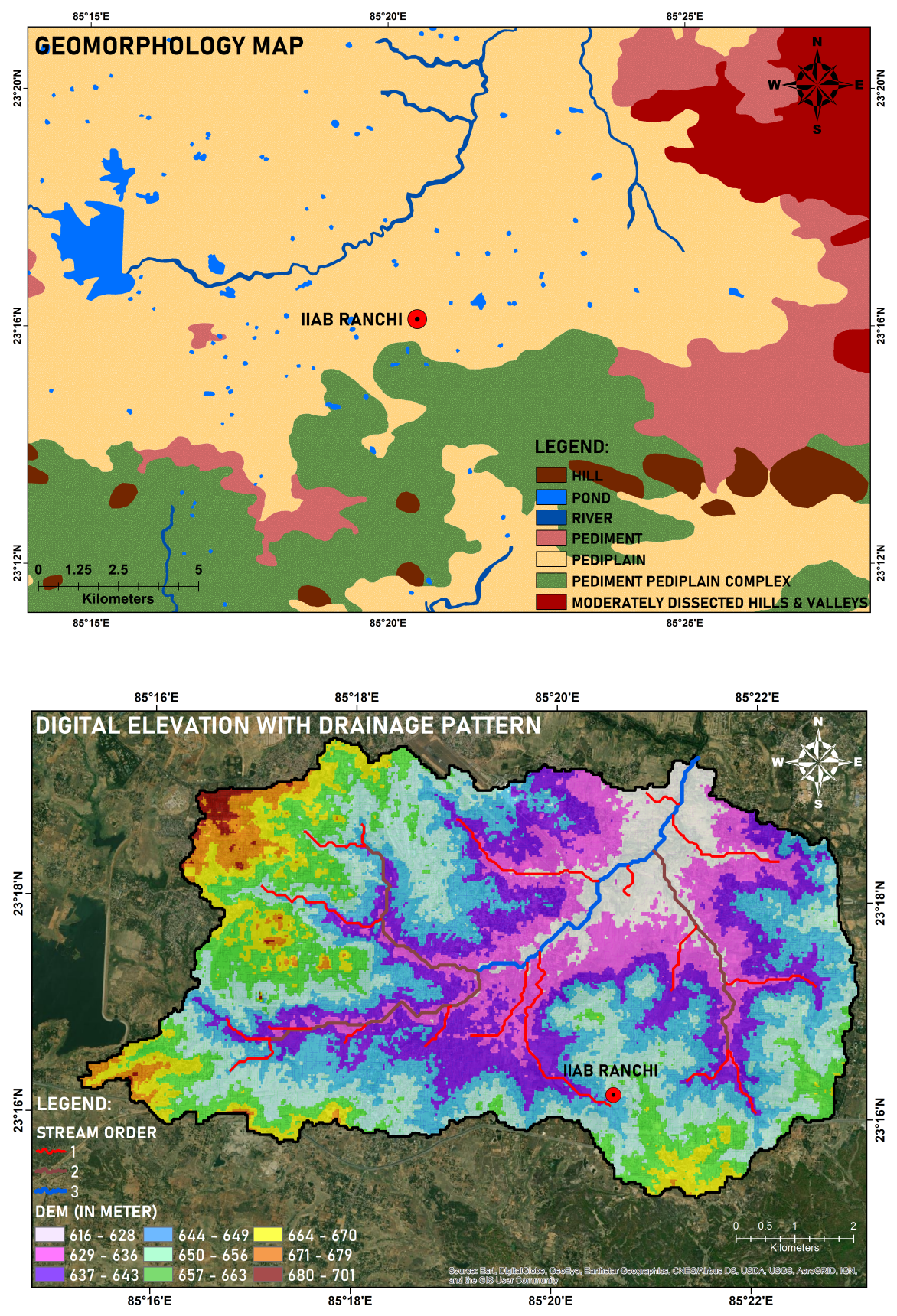

\section{Hosted file}

Fig5.docx available at https://authorea.com/users/421057/articles/527223-integrationof-geophysical-hydrogeological-and-geospatial-analysis-for-groundwater-assessment-inchotanagpur-granite-gneiss-complex-ranchi 


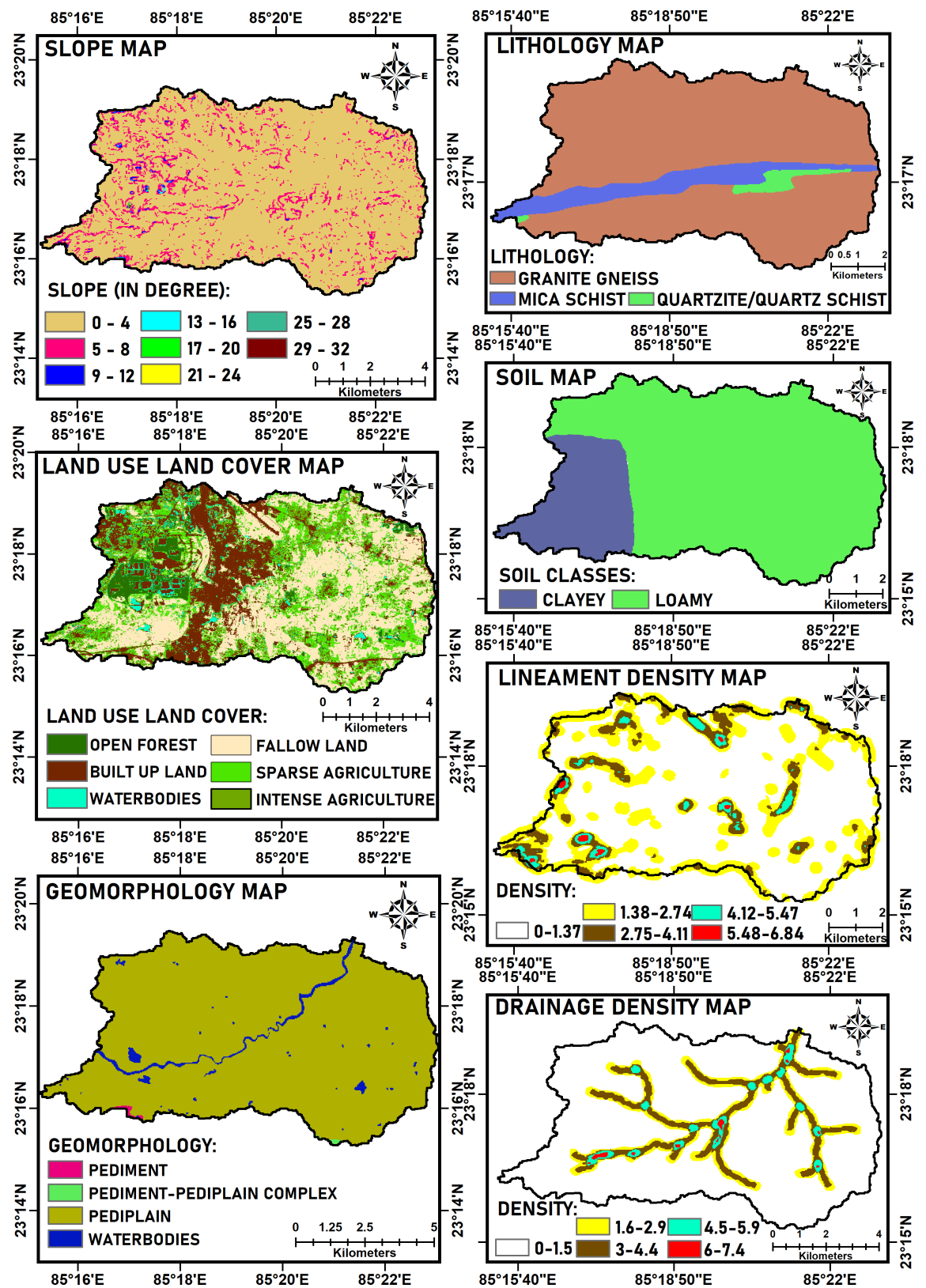




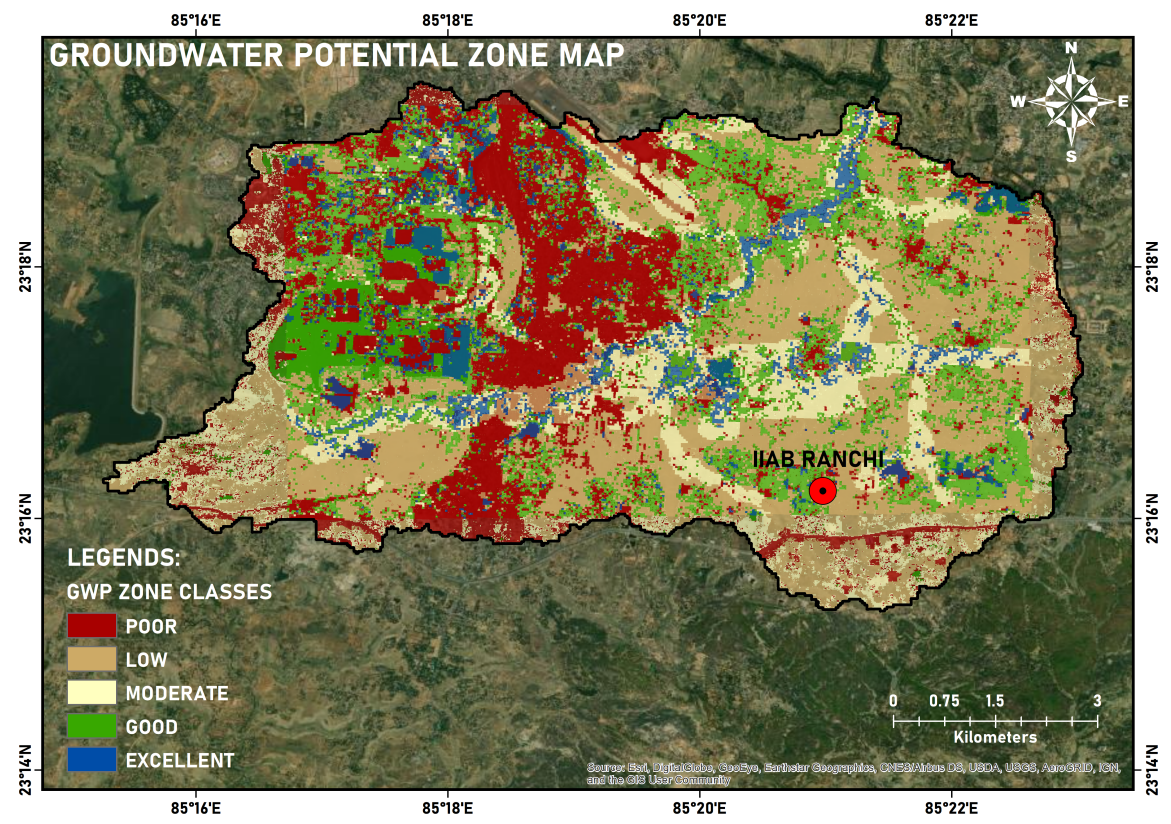

\section{Hosted file}

Fig8.docx available at https://authorea.com/users/421057/articles/527223-integrationof-geophysical-hydrogeological-and-geospatial-analysis-for-groundwater-assessment-inchotanagpur-granite-gneiss-complex-ranchi

\section{Hosted file}

Fig9.docx available at https://authorea.com/users/421057/articles/527223-integrationof-geophysical-hydrogeological-and-geospatial-analysis-for-groundwater-assessment-inchotanagpur-granite-gneiss-complex-ranchi

\section{Hosted file}

Fig10.docx available at https://authorea.com/users/421057/articles/527223-integrationof-geophysical-hydrogeological-and-geospatial-analysis-for-groundwater-assessment-inchotanagpur-granite-gneiss-complex-ranchi 


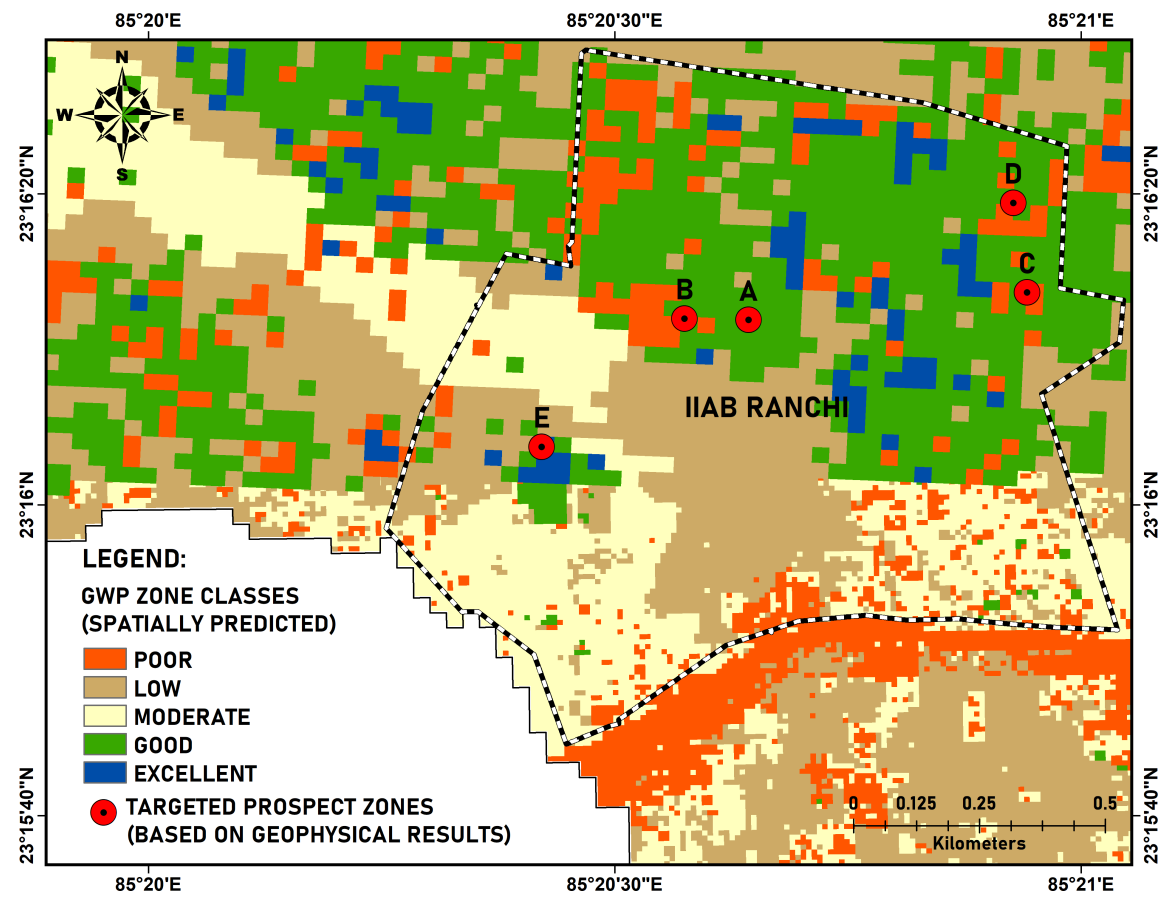

\section{Hosted file}

Fig12.docx available at https://authorea.com/users/421057/articles/527223-integrationof-geophysical-hydrogeological-and-geospatial-analysis-for-groundwater-assessment-inchotanagpur-granite-gneiss-complex-ranchi

\section{Hosted file}

Fig13.docx available at https://authorea.com/users/421057/articles/527223-integrationof-geophysical-hydrogeological-and-geospatial-analysis-for-groundwater-assessment-inchotanagpur-granite-gneiss-complex-ranchi 